\title{
The Implementation of Basic Principles of Journalism in Citizen Journalist's News on NETCJ
}

\section{Penerapan Prinsip Dasar Jurnalistik Pada Berita Kiriman Warga di NETCJ}

\author{
Erwin Kartinawati ${ }^{1}$, Rahmat Wisudawanto ${ }^{2}$ \\ ${ }^{1}$ Prodi Ilmu Komunikasi Universitas Sahid Surakarta \\ ${ }^{2}$ Prodi Ilmu Komunikasi Universitas Sahid Surakarta \\ J1 Adi Sucipto 154 Jajar Laweyan Surakarta, 57144 \\ erwinpurwasito@gmail.com
}

\begin{abstract}
The face of mass media has transformed extraordinarily after internet presence. The content was no longer the dominance of media because technology and the public can participate in producing and publishing news, which raised the phenomenon of citizen journalism. Mainstream media captured this phenomenon by bringing up programs based on news that sent by citizens. This research aimed to see the implementation of basic principles of journalism on news that sent by citizens, and the causes that influenced it, on www.netcj.co.id. The basic tenets seen were accuracy and fairness. The quantitative content analysis was used to see the first problem; then, the second problem was explored by interviews. The result showed that news sent by citizens on NETCJ mostly was inaccurate (55.17\%) and unfair (42.92\%). The differences in educational background and experience, the status of citizen journalists, and newsroom policy were the cause of the problem.
\end{abstract}

Keywords: Accuracy; Fairness; Citizen Journalism; NETCJ; Principles of Journalism

\begin{abstract}
Abstrak
Wajah media massa mengalami perubahan luar biasa pasca hadirnya internet. Konten tidak lagi menjadi dominasi media. Berkat teknologi, masyarakat dapat turut serta dalam membuat dan menyebarkan berita yang kemudian memunculkan istilah jurnalisme warga. Fenomena ini ditangkap oleh media arus utama dengan memunculkan beberapa program berdasar berita kiriman warga. Penelitian ini bertujuan untuk melihat penerapan prinsip dasar jurnalistik pada berita kiriman warga di www.netcj.co.id serta hal-hal yang memengaruhinya. Prinsip dasar yang dilihat adalah akurat dan berimbang. Metode analisis isi kuantitatif digunakan untuk melihat masalah pertama, sedangkan masalah kedua digali melalui wawancara. Hasil kajian menunjukkan jika berita kiriman warga di NETCJ, sebagian besar tidak akurat $(55,17 \%)$ dan tak berimbang $(42,92 \%)$. Perbedaan latar belakang pendidikan dan pengalaman, status jurnalis warga, serta kebijakan redaksi, menjadi penyebab persoalan.
\end{abstract}

Kata Kunci : Akurat; Berimbang; Jurnalisme Warga; NETCJ; Prinsip Jurnalistik 


\section{Introduction}

The face of mass media experiences extraordinary change after the presence of the internet. The content is not a domination of the media anymore. Formerly, the society depends on the information provided by media. Nowadays, society can produce and publish information extensively through various channels, mainly social media. Its distribution is also unstoppable because the information can be reduplicated easily and be redistributed rapidly (click and share).

This phenomenon is not considered insignificant by the mass media editors. It can be seen from the emergence of various information that uses viral content as the source of media content. Seeing the public's capacity in producing the information without depending on mass media as, like the previous era, mass media creates a program that accommodates this phenomenon, namely citizen journalism. Citizen journalism is a form of people's participation in producing the news by utilizing some channels like social media and mass media (Ross and Cormier, 2010), (Wall, 2018). This article only discusses the product of citizen journalism that is canalized by mass media. Some media that possess citizen journalism rubric ranges from Metro TV (Wide Shot), Net TV, Trans 7 (Cam-On), i-News TV, TVRI (Jurnalisme Khalayak), Kompas TV, and SCTV (Citizen6). As for Net TV, after seeing the high enthusiasm of the citizens in sending the news to the editor, that company launched "NET-CJ" in 2013 ("NetCJ-Help Support," n.d.).

However, citizen journalism is often lack of particular quality, notably relating to the implementation of the basic principles of journalism. Citizen journalism (CJ) comes from diverse and different backgrounds. A citizen journalist is not an official journalist, but he/she is like "a volunteer" who sends the news to media, including NETCJ. A citizen journalist is not like a professional journalist, although both do journalism activities. A professional journalist receives some specific training before going to the worksite. This is different from a citizen journalist that works based on initiative and creativity. This phenomenon is interesting to observe considering that the products of mass media have significant impacts on the public. The influence of mass media on shaping public perception is not questionable. Its capacity in distributing the information extensively, rapidly, and doubly makes media to select the accurate contents for the public.

In addition to being able to be accounted for the truth, the contents of mass media should not bring negative impacts on society. This relates to the functions of media as the source of information, entertainment, education, social control, and creating social cohesion (Laws of Republic of Indonesia Number 40 of 1999 concerning Press, n.d.). (Laws of Indonesia Number 32 of 2002 concerning Broadcasting, n.d.). Because of the difference in the background, the news produced by the citizen journalist should be a public concern, especially about the implementation of the journalism basic principles; has the news sent by citizens in the citizen journalist (CJ) program applied the basic principles of journalism? This needs to be observed because once the content is published, the public will not consider whether the news is produced by citizens who have adequate knowledge of journalism or not.

This research stems from the assumption that there is still much news created by citizen journalists that have published in mass media, including NETCJ, that do not meet the basic principles of journalism, particularly in the terms of accuracy and balance. One of the examples in the news entitled "Beware, Many Fake Eggs Circulate in the Market.

The Implementation of Basic Principles of Journalism in Citizen Journalist's News on NETCJ 
According to preliminary observation, this news is inaccurate because of the inconsistency between the title and the content. The news title impresses that there was fake eggs circulation, but the fact that was inscribed in the news video was the inspection of City Government of Parepare, South Sulawesi, to respond one of the citizens' post in Facebook who was aware of the originality of the eggs that she bought. The inspection found that there were no fake eggs. The condition of alleged fake eggs only changed because it was too long kept until the yolk became watery as like water. To be compatible with the fact, the news title, for example, could be changed into "Concerning the Alleged Fake Eggs, the City Government of Parepare Conducts Inspection," or "the City Government of Parepare: There is No Fake Eggs Circulation." Those news titles represent the fact and bring a more positive effect on society rather than the uploaded tittle. The selection of such a title could happen because, in addition to a lack of understanding, the "intentional" plan from the editor to attract viewers. Besides, it might also come from the citizen journalist who made a "bombastic" tittle intentionally to pass the editor selection.

Another example is the news about the durian festival in Klaten entitled "The Chaos in Durian Festival in Klaten." However, both picture and voice showed no supporting facts regarding the chaos. On the contrary, many people made happy faces and were scrambling when the Durian was distributed. The other example of unbalanced news can be viewed in the news entitled "Because of Factory Waste, Students Wear Masks in the Classroom" that was posted in July 2017. This news clearly mentioned one of the factory names that was alleged as the cause of air pollution until it disturbed the teaching and learning activities, but it did not accommodate the confirmation of the related party.

Figure 1. The screenshot of the example of inaccurate news

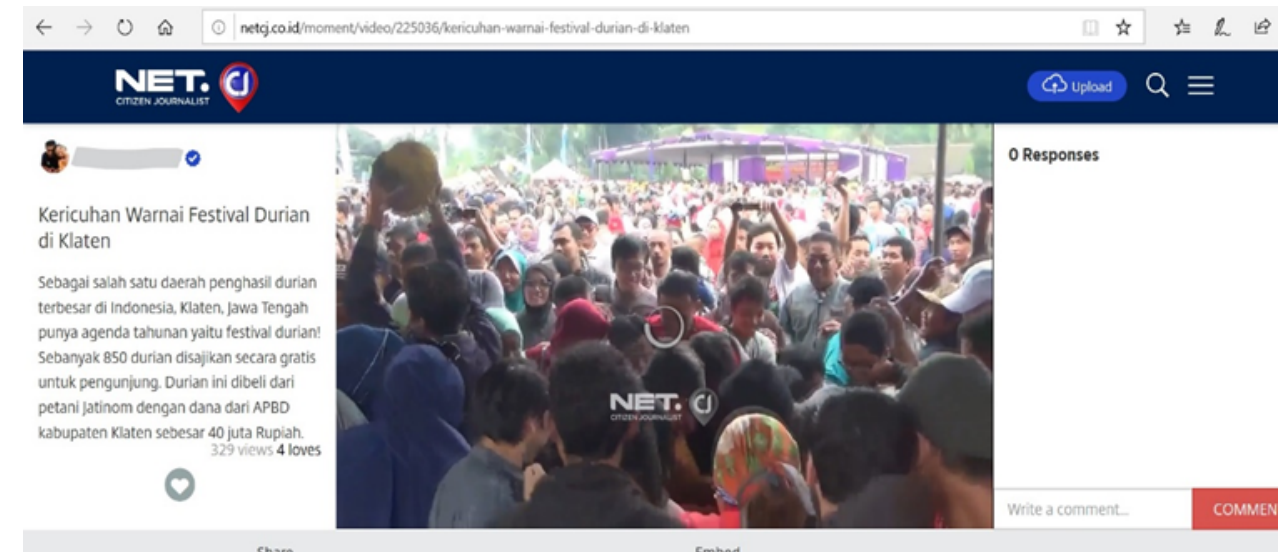

(Source: NETCJ, May 15th, 2018).

There has been numerous research on citizen journalism. However, the research only focuses on the problems of definition and effects on the work of professional journalists. Those can be seen through the investigations of Rabia Noor, Rani Ann Balaraman, et al., Greg Simons, Seungahn Nah, et al., and Kaylani Chadha and Linda Steiner. Rabia Noor (2017: 55-76) interviewed the journalists of mainstream media in Kashmir to understand their perception toward citizen journalists. The research stated that citizen journalism is not considered as a threat, but as a journalist who can provide benefits in filling information gaps that are not complied by mainstream journalists. In Malaysia, the research was done to comprehend the perception of citizen journalists about 
their activities (Balaraman, Ibrahim, Arokiasamy, and Mukhiar, 2016). Besides, the impacts of the presence of media social and CJ toward media in Russia had been observed with the result that the new media had pushed ahead of the development and the distribution of the information freely. The results of the research were gained by distributing the questioners toward journalists, teachers, and students. The research suggests that all elements of society should overcome the problems caused by the presence of the new media, including the phenomenon of CJ.

Generally, the presence of CJ was appreciated because it is a kind of enhancement of public participation (Simon, 2016). The presence of CJ as a proof of the improvement of public involvement also became the research conclusion published in Newspaper Research Journal Vol. 38(1). By applying quasi-experiment design, the research demonstrated that the practice of citizen journalism brings direct influence toward the enhancement of social participation and a nonprofit organization (Nah, Namkoong, and Record, 2017). That being said, some of the researches above have not investigated the quality of the news produced by citizen journalists, which becomes our focus of research. The quality of the news can be seen from the fulfillment of standards, basic principles, or professional rules that have been agreed internationally (Center for Media Transition, 2018). The accuracy of the information and the fairness of the facts presented to the public are a part of the basic principles to assess the news quality (Bogart, 2004).

Chada and Steiner had written the critic on CJ's news quality. This critic was based on their research result on CJ's news in CGNet Swara Chhattisgarh India, which was obtained by interviewing ten professional journalists. The presence of CJ was appreciated because they could cover the information that was not fulfilled by mainstream media and helped professional journalists in providing primary sources of the coverage (follow up). Unfortunately, the enthusiasm of the citizens in distributing information to society had not been accompanied by their understanding of the spirit of journalism (Chadha and Steiner, 2015). The research above is almost similar to this research, but Chadha and Steiner did not focus on the problems of CJ's news quality. Their research only observed the perception of professional journalists toward the potential and challenges of CJ'S phenomenon. Their research situation is also different from this research. The information analyzed by journalists in CGnet Swara is the genuine information in the form of share and comment, while the information in NETCJ has been through the process of publication which is as same as the information sent by professional journalists.

In NETCJ, not all news sent by citizens are proper to publish because it must pass the selection of properness and editing. Besides, CJ's news in NETCJ also become the content for some news programs in NET TV, those are NET5, NET24, and even own specific space in NET10. The high number of NETCJ members and the high productivity of the CJ in sending news to this media make the potency for publication is limited. Concerning the members their productivity, we will discuss it in the methodology chapter.

The specific researches about NETCJ have been done by Gaby Calisha Azzahra, Rendi Perdana, Mirza Ayu Anindita, and Cindy Mutia Annur. As this research, Azzahra (2018) took CJ's news and highlighted the framing of the chosen news in the video of the week. Rendi Perdana (2017) discussed the strategy of NET TV in packaging the CJ's news in NET10, Mirza Ayu (2014) discussed the role of CJ in presenting the information based on social phenomena, while Annur (2018) assigned the meaning of journalism ethics by CJ Surakarta. Those previous researches are different from this research that focuses on 
the news quality seen from the implementation of the basic principles of journalism. The result of this research can be utilized as the evaluation materials for the application of the basic tenets of journalism on the news published in mainstream media. The implementation of the principles of the news is strongly significant. It is due to the strategic position of media which must arrange the news optimally, those are the news which becomes a public concern and touches public interest. From this, the quality of the media can be measured. The news quality determines the credibility of the media industry (Bogart, 2004).

Based on the explanation above, the discussion of the topic in this research is about how the implementation of the basic principles of journalism in CJ's news in NETCJ and what does cause it. The basic principles of journalism will be focused on the problems of accuracy and fairness.

In producing news, the media is bound with technical and ethical aspects (Mursito, 2006). The technical element relates to the manner of collecting data and writing it, while the ethical element corresponds to the implementation of values, norms, and ethics. From those two aspects, the media in publishing news is prohibited from being arbitrarily based on personal or particular interest because journalism should be professional and responsible. The form of journalism responsibility, as stated by Kiith Windschuttle, is the commitment to report the truth. The obligation and responsibility of journalists are giving proper information for the public, not for delighting the advertiser or serving the state. The other responsibility of journalists is writing well, clearly, and properly. Besides, the media must present the news that is compatible with the available and consensus rules (Mursito, 2006).

The manners of the media in producing the news have been regulated in the laws and ethics code, those are the Laws of Pers Number 40 of 1999 which was derived into the ethics code of journalism, the Laws of Broadcasting Number 32 of 2002, and Broadcast Code of Conduct and Broadcast Program Standards (P3SPS). The Ethics Code of Journalism and P3SPS can be a benchmark for the quality of the news in media. For online media, there is cyber-media guidance that also contains the basic principles of journalism. The basic principles of journalism that are most emphasized are accuracy, balance, and objectivity.

Acquiring accurate and balanced news is the right of society. It is the responsibility of media in practicing its function as a social institution in addition to businesses institution. The highest award in the field of journalism, Pulitzer, uses the principle of accurate, fairness, in addition to his courage in conducting investigations as a primary element in determining the quality of the news (Shapiro, Albanese, \& Doyle, 2006). The qualified news is directly proportional to the success of the media business (Bogart, 2004). The quality of the news is as same as the credibility of the media. It means that the media credibility is as same as owning public trust. Without public trust, media organizations will not survive. The public trust is the pillar of the media business.

Citizen Journalism is a kind of citizen participation in the form of journalism activity in the digital era. The citizen journalists possess their platforms that are commonly shared through social media (Wall, 2018). To respond to this phenomenon, mainstream media accommodate the products of citizen journalism by creating a specific rubric for them. There are many nomenclatures for citizen journalism like grassroots journalism, open-source journalism, participatory journalism, hyperlocal journalism, distributed journalism, and networked journalism (Nurudin, 2010). 


\section{Methodology}

Quantitative content analyses were used to grasp the application of the basic principle of journalism to the news sent by the citizen journalists in NETCJ. Content analysis can be used to recognize the content of the characteristic of media objectively and systematically (Neuendorf, 2002). This method is useful for analyzing print or visual media (Eriyanto, 2011). This study is a systematic, factual, and accurate description of the facts and properties of particular objects. In other words, it is an examination to describe reality without explaining the intervariable relation or testing a hypothesis.

On the other hand, for identifying the cause of the problem in the application of basic principles of journalism, an in-depth interview was chosen. The researchers interviewed the CJ members of NETCJ based on sufficiency principles and editorial delegation. NETCJ was chosen due to the number of productivity and the amount of productivity. Until 2017, there were around five hundred thousand CJ spread in 75 countries (Annur, 2018). Other television tried to follow the successful path of NETCJ in organizing the media by conducting similar programs. Website video under the management of Net Mediatama used to receive an award as the best third in category news entertainment in Bubu Awards, competing with Kompas.com and Visual Interaktif Kompas (Indriaswari, 2017), (net_cj, 2017). Bubu award is a prestigious award in the digital creative industry. The award can be seen as an achievement because NETCJ was capable of competing with a big name in the media industry like Kompas although the age of NETCJ itself was still young. Citizen productivity in sending news in NETCJ was considered high at 50-150 news per day (Producer of NETCJ, Thomas Herda Mepilia: personal interview, December 3, 2019).

This research did not analyze news based on one specific case or theme, such as election, terrorism, disaster, and crime. Instead, it covered the general tendency. Therefore, it ignored differences in periods, and the researcher picked the random technique to collect the sample. This technique enables the researchers to generalize based on information obtained in the sample (Kriyantono, 2010). Each population has the same chance to be picked as a sample, and data from the sample was used to describe the characteristic of the population.

The population in the research was limited and selected from January to February 2019. The number of samples was $50 \%$ of the total publication, or 29 news samples were selected. The sampling used a simple random technique where all population was given number before randomized until the number of samples was determined (Kriyantono, 2010). The sample chosen was news which was categorized as 'moment.' The assumption behind that is the importance and actuality of the news, as opposed to another category, which is closer more to human interest.

Table 1. List of the news sample (Sumber : www.netcj.co.id)

\begin{tabular}{lll}
\hline No & Edition & Title \\
\hline 1 & 270219 & $\begin{array}{l}\text { Japanese Festival: a Real Example Australian People Love } \\
\text { Japanese Culture }\end{array}$ \\
2 & 270219 & $\begin{array}{l}\text { Many Danish Citizen Interested in Indonesia } \\
\text { Reog Ponorogo Fascinated in National Multicultural Australia }\end{array}$
\end{tabular}

The Implementation of Basic Principles of Journalism in Citizen Journalist's News on NETCJ 


$\begin{array}{lll}4 & 250219 & \text { In Parepare Expo the Kid Can Make an ID Card } \\ 5 & 210219 & \text { Watch out! Plague Attack Farmers' Rice } \\ 6 & 210219 & \text { Now, Tarakan Residents Can Enjoy Natural Gas Service } \\ 7 & 180219 & \text { Find A Wasp Nest? Call Them! } \\ 8 & 180219 & \text { The Cheerfulness of Nongsa Neptune Sail to Lingga 2019 } \\ 9 & 150219 & \text { Indonesian Students Celebrates Russian Student Day } \\ 10 & 130219 & \text { After Snowstorm, American Citizens Do Sledding } \\ 11 & 120219 & \text { Cool! Pencak Silat Started to be Popular in Europe } \\ 12 & 080219 & \text { Indonesia Calls for Young and Talented Shooters! } \\ 13 & 070219 & \text { Durian Season Has Come, Let's Come to Durian Randulanang! } \\ 14 & 060219 & \text { You Can Do This to Prevent Dengue Fever } \\ 15 & 050219 & \text { A Tradition to Bathe Statue of a God to Acquire Bless } \\ 16 & 040219 & \text { Vihara Refurbished to Welcome Lunar Day } \\ 17 & 010219 & \text { A couple of Ape Come Back to the Habitat } \\ 18 & 010219 & \text { Around Ten Thousand Caterpillars Attack Residences } \\ 19 & 310119 & \text { Lookout! Dengue Fever Starts to be Epidemic } \\ 20 & 280119 & \text { Snowstorm Makes Midwest Temperature Cooler than the Artics } \\ 21 & 280119 & \text { Mahoni Mental Hospital Prepared for Failed Representatives } \\ 22 & 270119 & \text { Typhoon Stroke 3 Villages in Jepara } \\ 23 & 210119 & \text { Exciting! Online Game Tournament with Million Rupiahs Prize } \\ 24 & 170119 & \text { In Fact, Many Students Are Playing Truant } \\ 25 & 160119 & \text { The Romantics Festival of Light Kaliurang 2019 } \\ 26 & 150119 & \text { Diesel Fuel Spilled in Parepare Waters, the Resident Scramble } \\ 27 & 110119 & \text { A Coffin of Toraja Ascendant Fall from A Cliff } \\ 28 & 090119 & \text { A Project Building of FEB IAIN Palopo Worth 22 Million } \\ 29 & 040119 & \text { Burned } \\ & \text { Teak Defoliator Pest Attack Residents, Can Make Itchy! }\end{array}$

To make sure that the researchers' bias did not contaminate the study, the reliability test used with Holsti formulation $\mathrm{R}=2 \mathrm{M} /(\mathrm{N} 1+\mathrm{N} 2)$ was executed.

\section{Description: R: inter-coder reliability \\ M: Number of coding agreed by each coder \\ N1: Number of coding agreed by coder 1 \\ N2: Number of coding agreed by coder 1}

The research used conceptual and operational definitions regarding accuracy and fairness. Accuracy is based on the objective situation when the event happens. There should be a correspondence between a fact and the real condition (KEJ, 2006). Accuracy, that is to say, is an exact, careful, or thorough examination including the fact that each statement in the news. The name, position, title, location, day and date, work or expression or definitive sentence, numbers or statistics, should be presented precisely and never induce misunderstanding, whether for people that are reported or reader. Also, apart from the detailed and specific fact, the whole connection of news is essential (Romli, 2003).

Based on the concepts above, the evaluation of accurate news was operated as follows: unambiguous informant (citing source): competence-based informant selection (name, status, position, title, age, expertise, and so on): precise in mentioning the name of organization, institution, abbreviation; correct in mentioning title and location of the 
event; coherence between title and content; coherence between lead and the content of the news; consistency in narrative and picture; complete and clear in including aspects in news $(5 \mathrm{~W}+1 \mathrm{H}$ formula).

On the other hand, fairness means to cover both sides. That is to say, being equal in placing informant, in giving time, neutral in the content (not taking a side) should be conducted. Impartiality contains fairness and neutrality (Mcquail, 2011). News is impartial if there are tight relationships with other facts and capable of establishing an essential correlation with whole sequences of events. Facts are presented completely to make sure that the audience can assimilate the whole picture, or a balanced perspective of all vital situation is reported. These components can be seen from the representation of the sources cited in the coverage, tendencies in exaggerating statement in coverage through compliment or criticism, and impartiality in delivering data and fact in the news

Against that background, news can be said partial if these elements appear: only giving a description of an event or condition of a party without involving another party at the same time. As a result, the news is not completed when it is displayed. Another operational is taking a side, exaggerating one party without evidence or logical explanation.

Data analysis technique with simple binary coding to show whether there is a category that was made in the operational definition appeared in the document (Slamet, 2006). The finding was described in the frequency table (Eriyanto, 2011). The result of the interview was described and focused on the factors that affected the application of the basic principle of journalism in citizen journalism.

\section{Results and Discussion}

To prevent subjectivity from an evaluation, a reliability test with agreement intercede at least of $70 \%$ should be fulfilled (Eriyanto, 2011). The result of the coding showed agreement at 0,793 , whether for accuracy category or fairness. It implies that the instrument made is reliable or acceptable.

Table 2. Reliability of Accuracy Category (Source: Research analysis)

\begin{tabular}{cc}
\hline Formulation & Result \\
\hline $\mathrm{R}=2 \mathrm{M} /(\mathrm{N} 1+\mathrm{N} 2)$ & $(2 \times 23):(29+29)=0,793$ \\
\hline Table 3. Reliability of Fairness Category (Source: Research analysis) \\
\hline Formulation & Result \\
\hline $\mathrm{R}=2 \mathrm{M} /(\mathrm{N} 1+\mathrm{N} 2)$ & $(2 \times 23):(29+29)=0,793$ \\
\hline
\end{tabular}

After testing the reliability, the result of evaluation towards news that was accurate and not, and fair and not, was acquired 
Table 4. Evaluation of the accuracy of news $(n=29)$ (Source: Research analysis)

\begin{tabular}{ccccc}
\hline Coder & Acurate & Percentage & Inaccurate & Percentage \\
\hline 1 & 13 & 44,83 & 16 & 55,17 \\
2 & 12 & 41,38 & 17 & 58,62 \\
\hline
\end{tabular}

Table 5. Evaluation of the accuracy of news $(n=29)$ (Source: Research analysis)

\begin{tabular}{ccccc}
\hline Coder & Fair & Percentage & Unfair & Percentage \\
\hline 1 & 10 & 34,48 & 19 & 42,92 \\
2 & 16 & 55,17 & 13 & 44,83 \\
\hline
\end{tabular}

The tables above show that news sent by the citizen was problematic since news published that was inaccurate and unfair were more numerous that news that is accurate and fair. News that was unaccurate can be seen in news number 1, 3, 4, 7, 9, 10, 11, 12 , 20, 21, 22, 24, 25, 27, 28, and 29. For example, a coverage entitled "Teak Defoliator Pest Attack Residents, Can Make Itchy!' was inaccurate since not only the informants' selection was not appropriate, but also the title and the content were incoherent. At that news, the informant that was interviewed was a resident who was never attacked by the caterpillar. A question arises: How could a person who has never get struck by teak caterpillar capable of describing the feeling? Despite the incoherence with the title, the news also did not correspond with the statement of the informant. The title of the reportage might be more accurate if it was entitled "Teak Defoliator Attack Disturb the Activity of Residents." In addition, apart from the quote from the informants, in the narrative, it was mentioned that the attacks did not induce itchiness but complaint because the teak caterpillar left spot on the shirts of the residents. If so, why did the writers conclude that the attack resulted in itching skin?

Also, the news did not cover which location that was attacked by the caterpillar, since when it had happened, how were the actions of the related institutions? How dangerous? What were the causes? The questions should be answered in the news so that the public can elicit the picture of the fact delivered utterly. A complete, comprehensive, and clear writing is one of the parameters of accuracy. Accurate news is more crucial than fast and exclusive news. Professional journalists always try to make their information reliable, fast, and exclusive. However, exclusive news is useless if the news is not accurate.

Elicit Accurate news is the right of everyone. Trustworthy news or at least news that is approximate to truth is also more vital than actuality. A way to obtain accurate news is by dodging mistakes (Ishak, 2014). Finding and apprehending facts from a competent informant is also an effective method. This news, therefore, should pick competent interviewees. 
Figure 2. The screenshot of inaccurate news because the title and the content are inaccurate, as well as the poor informant selection

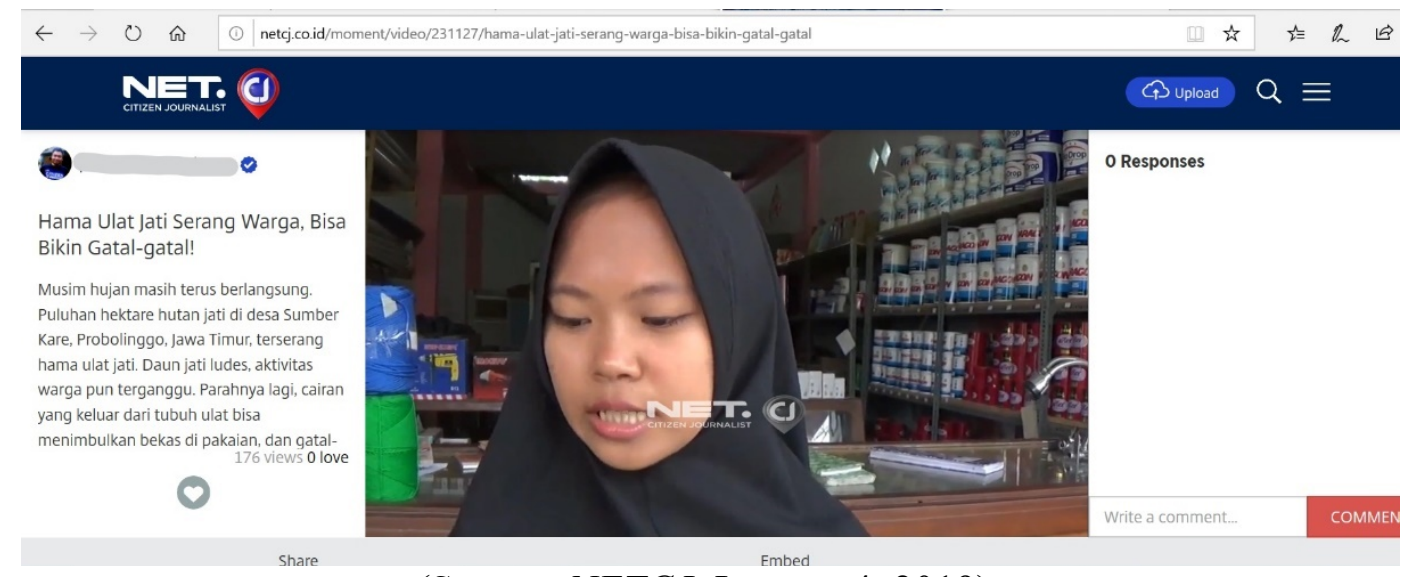

(Source: NETCJ, January 4, 2019).

Apart from unfounded informant selection, which made the CJ news inaccurate, the informants were not problematic as well. For example, a reportage entitled "In Parepare Expo the Kid Can Make an ID too," the news was a narrative without support from competent sources. Also, the title only covered a small part of the real event. It would be appropriate if the title became "Parepare Expo." In this news, the source was an attendant who was asked about the exhibition as a whole, and not the organizers. If the organizer was not interviewed regarding the event, how could the CJ gain the information about the news? Was it from observation?

Although the news was indeed made from observation, it should also be equipped with interviews. These two processes, based on the researcher experience as journalist and $\mathrm{CJ}$, are required and complete each other as a form of the validity of the news. It is a signal that the fact has been checked and re-checked. Check and recheck cannot be adequate if it was done only between informants; it should also be strengthened by observation and confirmed with the interviews. Or interview that is corroborated through personal observation of the journalists.

Accurate news is one of the public rights to elicit information as it is. The accuracy of news is essential for journalist credibility and the media where the journalists publish their work. Credible news equals to public trust (Peters \& Broersma, 2013). Without trust, journalism work is useless. Journalism's works aim to acquire public trust because it determines the economic function of media. Owing to the trust, the public supports the media through advertisement; the key principle why media can operate continuously.

Publishing news with credible sources is one of the ten primary steps of CJ, Blogger, or Cyber Journalist to be averted from lawsuits (Rosenberg, n.d.). The heartbeat of journalism is the source. Being a journalist is the same with expanding sources, including from observation. Interviewing different sources is a form of discipline verification. It is necessary to avoid distortion that leads to the credibility of the news made (Iswara, 2005).

The journalism claim, or a type of journalism that attempts to conclude subjectively a fact, results from lack of definite source. It is the reason much news sent 
by the citizen inaccurate. The existence of competent and founded sources in news is a way to verify facts and make it be news. Verification is the heart of journalism. To survive, verification cannot be ignored because credibility is at stake (Romli, 2018). One of the ways to verify is by not making an assumption (Kovack \& Rosenstiel, 2003).

Consider news entitled "Indonesia Calls for Young and Talented Shooters," and "Snowstorm Makes Midwest Temperature Cooler than the Artics," as examples. The news regarding snowstorm was not accurate since the basis of information was questionable. The narrative mentioned that the residents should not get out of the house and prepare foods in cars if a trip is inevitable. Did the instruction come from a personal recommendation of the CJ or the local authority? Also, essential information looked missing in the reportage, such as how long and until when? How cold was the Arctic compared to Midwest?.

Inaccuracy in information, again, mostly occurred due to the problem of verification of fact. Accuracy has been admitted as a recent problem of media. Indeed, according to Robert I. Berkman and Christopher A. Shumway, it is related to the high competency in business, apart from the need to publish a high amount of news. The issue also contaminates online media. Verification, therefore, was a step that should be concerned by online media (Haryanto, 2014).

Inaccuracy was also associated with mistakes in using terms, such as in the news entitled "Lookout! Dengue Fever Starts to be Epidemic." The use term of an epidemic is questionable since it did not ascertain whether it comes from the journalist or informant. An epidemic is a status of a condition that cannot be announced arbitrarily. Although the number of victims due to Aedes Aegepty Mosquite's bite was numerous, the announcement of an epidemic should have met specific criteria. Moreover, the Indonesian Ministry of Health used to suggest that journalists should pay attention to the detail of health status during news making-process. An event can be categorized as an epidemic if there are significant increasing cases in a short period, together with causing worry in society, disturbing security, and harming the economy. Before the status of an epidemic is announced, there should also be an extraordinary event, starting from the regional level, province, to national (Abdi, n.d.).

Choosing terms precisely may not be considered essential by the journalist. The reason can result from ignorance, lack of supervision, and protest from internal and external media. Nevertheless, the media needs to understand detail. This is because not only should the media ascertain the accuracy of the information, but also the media has a function to educate people. Mass media has a task to inform the nation through educative content by publishing correct information or correcting wrong information. By delivering accurate and precise knowledge of dengue fever, the media is educating the public. News published should not only inform the victims that need special treatments and the surround residents for being more alert and therefore reducing the risk of getting infected, but also explaining the level of the status of dengue fever in a region.

To accurately use terms in reportage is crucial in emergency or disaster. A mistake in term use may cause fatal consequences, starting from worry, conflict, until fatality. As exemplified by Sukmono and Junaedi (2018: 714-715) during Merapi eruption in 2010, a reporter erroneously mentioned volcanic ash rain with hot cloud or widely known by the people around the area as wedhus gembel. Consequently, some fatalities could not be mitigated.

Inaccuracy is also related to incomplete presentations of fact. The consequence is that the news becomes less clear, and the public cannot grasp the complete picture of the 
information presented, such as when and where the situation occurs. Simplification to describe a number should also be a concern. Admittedly, simplicity is one of the basic principles of audiovisual news (keep it short and simple) because of its transitory nature. The human brain is hard to remember detail information and quickly gets bored with that type of information. Furthermore, short and simple is a character of online media because it adjusts the increasing level of business. Online media addresses the problem of time on how society can elicit information despite the limited time they have (Romli, 2018). That being said, presenting short news is not only about trimming duration. Short does not mean not offering news comprehensively. Instead, it should be understood as an ability to present dense but utter news with a limited amount of time. "Japanese Festival is a Real Example Australian People Love Japanese Culture," is an adequate example of the criteria.

On the other hand, an example of unfair news can be seen on news entitled "Diesel Fuel Spilled in Parepare Waters." There was no clarification from the side who spilled the fuel. Indeed, the day after, no coverage activity followed up the situation. It reveals another problem of CJ, namely a lack of clear agenda to cover an occurrence. Consequently, what is presented is rarely comprehensive as what happened to news regarding Parepare Waters in South Celebes. The public then cannot gain complete and advantageous information but not maximum news.

The news mentioned is highly potential due to the effect on society, notably for marine life. Unfortunately, the ending of the news was not covered. The question is "did the CJ not make follow-up? Or he made one but not accepted by the editors? Granted, the decision of publication is in the editor's hand. However, a question that should be asked is that "has the CJ confirmed the news?" in the news, the CJ only mentioned that "there was no comment from the terminal." What does it mean by comment was not available yet? Has the CJ asked for a comment, but the person in charge did not give it? Or has the CJ asked, but the feedback was postponed?

If the CJ has not asked for commentary, the statement mentioned is not supposed to appear, but if the CJ has asked, the reaction of the person in charge should be described clearly to avoid misunderstanding among society. For the affected community, clarity regarding how significant the consequences, how long the process of cleaning up the spill, and how dangerous this is for society and marine life, is needed. It implies that fairness function in the news is not only about giving an opportunity of related side to voice in the same proportion, but also the right of the public. Obtaining a fair report is as essential as obtaining accurate news. By eliciting fair news, the readers can be more aware since the issue is complete, certain, and clear, and there is no questionable information.

Unverified journalism is considered a modern press culture. The development of the internet breeds audiences that always hunger for the most actual information. They want to get information that is fast and real-time. As a result, the media often presents uncomplete news (Widodo, 2010). Verification is deemed another problem regardless of the fact that verification is a primary instrument to produce accurate news. Accuracy is the vital foundation news, and the core is verification (Kovack \& Rosenstiel, 2003). Other unfair news can be seen in samples number $1,4,5,7,8,9,10,11,12,13,14,18,20,21$, 22, 23, 24, 25, 26.

The interviews with six CJ and one of the editorial delegation confirmed the result of the analysis that accuracy and fairness were the elements that were highlighted the

The Implementation of Basic Principles of Journalism in Citizen Journalist's News on NETCJ 
most. The reason for the incapability of the CJ to meet the basic principle of journalism was mostly caused by educational background, experience, status, and editorial roles. The CJ was not a journalist; rather, it was citizens that ran process or activity similar to journalists, but and sent it to particular media. A journalist is supposed to experience training in advance before going off to the worksite, even if not all the journalists have a journalism background. Periodically, media organizations typically conduct training and workshops to improve the skills of journalists.

The process usually abstains from CJ. A CJ is a volunteer, and they have different educational backgrounds and routine. The differences in the educational background make the skill of CJ in making news also be varied. It is not surprising if not all $\mathrm{CJ}$ comprehend the basic principle of journalism. They who never have journalism education or experience usually sharpen their skills autonomously by emulating the pattern of news that is presented (interview with informants 1,2,3,4). After some time, their capability is enhanced so that they experience improvement, including their understanding of the importance of applying the journalism process. Editors also play a significant role in the development despite not maximal. Lack of experience in writing news or participating in journalism training becomes one of the reasons that many reportages sent by the citizen do not meet basic journalism principle.

The status of $\mathrm{CJ}$ that works like a journalist without bearing any flag sometimes made difficulty for the $\mathrm{CJ}$ itself in the process of making a comprehensive report. This is because not all informants are willing to be interviewed, notably about sensitive information (personal interview, Thomas Herda-Producer of NETCJ, 14 Juni 2019). The status of $\mathrm{CJ}$ that is not official also prevented the editor from pushing the $\mathrm{CJ}$ to make news that was accurate and fair. It is different from official journalists. The editors had full authority towards the journalist to push them to meet the standard in any aspect (Interview with informant number 2, May 27, 2019).

With that in mind, the editors highly figured in determining the quality of news sent by the citizen. The educational background and the experience of the CJ who did not come from journalism can be tackled if the editors played it pivotal role, notably in enhancing the quality of CJ, whether formally or informally. While formally, the editors can hold special training regarding technique in making standard news, informally it can be done by giving periodical evaluation (Interview with informant 3, May 31, 2019).

Concerning the news that does not meet journalism standards but was broadcasted nevertheless, according to Thomas Herda, it is related to the policy of media. Since the program was for $\mathrm{CJ}$ and not for the journalist, some problems were understandable.

\section{Conclusion}

The result from investigating the 29 sample news sent by citizens in NETCJ from January to February 2019 has shown that many news was still not met the basic principle of journalism, notably in the accuracy $(55,17 \%)$ and fairness $(42,92 \%)$. The reason for the inaccuracy is that the information was not comprehensive that could make the report less clear and need further investigation. The other reason is that many news relied solely on observation of the $\mathrm{CJ}$ without equipped with the statement from credible informants. Incoherence between the content and the title, together with the unclarity incomprehensive in delivering information so that the public cannot utterly elicit information delivered, also became a concern. For fairness, the CJ tended to report the news with only one side that made the fact unverified. Accuracy and fairness are highly 
related and should be fulfilled. That is to say, when news is presented accurately, it will be fair, and when news is presented fairly, it will be accurate.

On the other hand, the reason for which the journalism works, which were published on the website, did not meet the basic principle of journalism is varied from the educational background, experience, the status of CJ as inofficial journalists, and intervention. This result implies that improvement in the quality is instructive.

Both the CJ and editors can conduct quality improvement. Initiation to develop CJ should not only be limited to writing skills, camera use, or photography, but also willingness to understand, at least to read the information regarding the law, rule, and ethics of journalism. Comprehension of the foundation of law and ethics of journalism can automatically affect the way CJ presents a fact in the report to the public. The role of editors to maintain the quality can be achieved by conducting periodical evaluation and training. Making standard for clear and unambiguous news could also be done to alleviate the gap among news produced.

$\mathrm{CJ}$ is not an official journalist of media regardless of the effect that sometimes impactful. This study does not intend to dwarf citizen journalism products nor conventional press; instead, it is an attempt to develop and maintain the quality of the press product. An excellent press reflects the excellency of the public. Therefore, the outcome of journalism should elicit advantageous knowledge for society. It can be made possible as long as the function of education and social control of journalism are executed thoroughly without ignoring the entertainment and information side of this sector.

The research recommends that the shift in resources and strategy of mass media in producing news, as well as the effect on the quality and the perception of the public about the phenomenon, can be considered as further research. It can be a form of social participation in controlling the quality of the media.

\section{Acknowledgments}

The research is funded by the Directory of Research and Community Service of Indonesia Ministry of Research, Technology, and Higher Education, in New Lecturer Research Scheme (PDP) 2019.

\section{References}

Abdi, A. P. (n.d.). Kemenkes Imbau Media Pahami Wabah dan KLB Soal DBD. Retrieved April 4, 2019, from 30 Januari 2019 website: https://tirto.id/kemenkesimbau-media-pahami-wabah-dan-klb-soal-dbd-dfr5.

Anindita, M. A. (2014). Peran Citizen Journalism dalam Menyajikan Informasi Kepentingan Publik Melalui Media Massa: Studi Kasus di NETCJ. Universitas Indonesia.

Annur, C. M. (2018). Pemaknaan Etika Jurnalisme Warga oleh Jurnalis Warga NETCJ di Wilayah Solo: Studi Fenomenologi Mengenai Etika Jurnalisme Warga. Padjajaran.

Azzahra, G. C. (2018). Analisis Pembingkaian Berita dalam Tayangan Net Citizen Journalist (Airlangga). Retrieved from http://repository.unair.ac.id/70700/1/ABSTRAK_Fis.K.49 18 Azz a.pdf

Balaraman, R. A., Ibrahim, F., Arokiasamy, L., \& Mukhiar, S. N. S. (2016). Kewartawanan Warga di Malaysia: Satu Kajian dari Sudut Pandangan Wartawan 
Warga. Jurnal Komunikasi: Malaysian Journal of Communication, 32(2), 277-293. Bogart, L. (2004). Reflections on Content Quality in Newspapers. Newspaper Research Journal, 25(1), 40. https://doi.org/10.1177/073953290402500104.

Center for Media Transtition. (2018). The Impact of Digital Platforms on News and Journalistic Content. Retrieved from https://www.accc.gov.au/system/files/ACCC commissioned report - The impact of digital platforms on news and journalistic content $\% 2$ C Centre for Media Transition \%282\%29.pdf\%0D

Chadha, K., \& Steiner, L. (2015). The Potential And Limitations of Citizen Journalism Initiatives. Journalism Studies, 16(5). Retrieved from https://www.tandfonline.com/doi/full/10.1080/1461670X.2015.1054179.

Eriyanto. (2011). Analisis Isi : Pengantar Metodologi untuk Penelitian Ilmu Komunikasi dan Ilmu-ilmu Sosial lainnya. Jakarta: Prenada Kencana Media Group.

Haryanto, I. (2014). Jurnalisme Era Digital : Tantangan Industri Media Abad 21. Jakarta: Kompas.

Indriaswari, R. (2017). Wishnutama Sabet Penghargaan di Bubu Awards. Retrieved May 28, 2018, from 28 September 2017, 23:31 WIB website: https://netz.id/news/2017/09/28/00516-01616/1024280917/wishnutama-sabetpenghargaan-di-bubu-awards.

Ishak, S. (2014). Jurnalisme Modern. Jakarta: Elex Media Komputindo.

Iswara, L. (2005). Jurnalisme Dasar. Jakarta: Kompas.

Kode Etik Jurnalistik, No. 03/SK-DP/2006 (2006).

Kovack, B., \& Rosenstiel, T. (2003). Sembilan Elemen Jurnalisme. Jakarta: Yayasan Pantau dan Kedutaan Besar AS.

Kriyantono, R. (2010). Tehnik Praktis Riset Komunikasi. Jakarta: Prenada Kencana Media Group.

Mcquail, D. (2011). Teori Komunikasi Massa (6th ed.). Jakarta: Salemba Humanika.

Mursito. (2006). Memahami Institusi Media: Sebuah Pengantar. Surakarta: Lindu Pustaka dan SPIKOM.

Nah, S., Namkoong, K., \& Record, R. (2017). Citizen Journalism Practice Increases Civic Participation. Newspaper Research Journal, 38(1), 62-78. https://doi.org/10.1177/0739532917698444

net_cj. (2017). No Title. Retrieved from 30 September 2017 website: https://www.instagram.com/p/BZpcReujwzh/?igshid=jxo5wxxi3obs

NetCJ-Help Support. (n.d.). Retrieved from http://netcj.co.id/about_us

Neuendorf, K. A. (2002). The Content Analysis Guidebook. Sage Publications.

Noor, R. (2017). Citizen Journalism vs. Mainstream Journalism: A Study on Challenges Posed by Amateurs. Athens Journal of Mass Media and Communications, 3(1), 5576. https://doi.org/10.30958/ajmmc.3.1.4

Nurudin. (2010). Citizen Journalism sebagai Katarsis Baru Masyarakat. Yogyakarta: Litera Buku.

Perdana, R. (2017). Strategi Penyajian Jurnalisme Warga pada Tayangan Citizen Journalist di Program Net 10 (Studi Kasus di Net. IISIP Jakarta.

Peters, C., \& Broersma, M. (Eds.). (2013). Rethinking Journalism: Trust and Participation in a Transformed News Landscape. New York: Routledge.

Romli, A. S. M. (2003). Jurnalistik Terapan dan Kepenulisan. Bandung: Batic Press.

Romli, A. S. M. (2018). Jurnalisme Online. Bandung: Nuansa Cendikia.

Rosenberg, G. P. (n.d.). 10 Rules for Limiting Legal Risk. Retrieved April 30, 2019, from www.kcnn.org 
Ross, R., \& Cormier, S. C. (2010). Handbook for Citizen Journalist. Retrieved from https://archive.org/stream/HandbookForCitizenJournalists/HandbookForCitizenJou rnalists_djvu.txt

Shapiro, I., Albanese, \& Doyle, P. L. (2006). What Makes Journalism "Excellent"? Criteria Identified by Judges in Two Leading Awards Programs. Canadian Journal of Communication, 31, .426-427.

Simon, G. (2016). The impact of Social Media and Citizen Journalism on Mainstream Russian News. Russian Journal of Communication, 8(1).

Slamet, Y. (2006). Metode Penelitian Sosial. Surakarta: UNS Press.

Sukmono, F. G., \& Junaedi, F. (2018). Jurnalisme Sensitif Bencana dalam Manajemen Pencarian, Pengelolaan Informasi dan Pemberitaan Bencana di Ruang Redaksi. Jurnal ASPIKOM. https://doi.org/10.24329/aspikom.v3i4.185

Undang-Undang Republik Indonesia No. 32 Tahun 2002 tentang Penyiaran.

Undang-Undang Republik Indonesia Nomor 40 Tahun 1999 tentang Pers.

Wall, M. (2018). Citizen Journalism : Practices, Propaganda, and Pedagogy. UK: Routledge.

Widodo, Y. (2010). Menyoal Etika Jurnalisme Kontemporer: Belajar dari OhmyNews. Jurnal ASPIKOM, 1(1), 41. https://doi.org/10.24329/aspikom.v1i1.7. 